\title{
FUNCTIONS OF SYMBOLIC SIGNS OF GESTURES AND FACIAL EXPRESSIONS IN FICTION (BASED ON THE MATERIAL BROKEN SWORD NOVEL BY T. KASYMBEKOV)
}

\author{
CEltuzerova G., Kyrgyz National University named after Jusup Balasagyn, \\ Bishkek, Kyrgyzstan, Eltuzerovagulzina@mail.ru
}

\section{ФУНКЦИИ ЖЕСТОВ И МИМИКИ В ХУДОЖЕСТВЕННОМ ТЕКСТЕ (НА МАТЕРИАЛЕ РОМАНА Т. КАСЫМБЕКОВА «СЛОМАННЫЙ МЕЧ»)}

\author{
(СЭлтузерова Г. Ж., Киргизский национальный университет им. Жусупа Баласагына, \\ 2. Бишкек, Kыргызстан, Eltuzerovagulzina@mail.ru
}

Abstract. The article is devoted to the actual problems of the modern Kyrgyz language. The main object of the research is the study of the semantics of symbolic gestures and the facial expressions of a literary text in the linguistic aspect. Semantics of symbolic gestures and facial expressions in the literary text in the transmission of information is analyzed on the basis of the example of an excerpt of the texts of the Broken Sword novel by T. Kasymbekov. The results of the study based on the interpretation of symbolic national facial expressions and gestures in the linguistic aspect.

Аннотащия. Статья посвящена актуальным задачам современного кыргызского языка. Основным объектом исследования является изучение семантики символических жестов и мимики художественного текста в лингвистическом аспекте. Семантика символических жестов и мимики в художественном тексте при передаче информации проанализирована на примере отрывков из текста романа Т. Касымбекова «Сломанный меч». Изложены результаты исследования на основе интерпретации символических национальных жестов и мимики в лингвистическом аспекте.

Keywords: symbolic gestures, pointing gestures, submissive gestures, demonstrative gestures, non-verbal means, communication process, nod.

Ключевые слова: символические жесты, указательные жесты, подчеркивающие жесты, демонстративные жесты, невербальные средства, коммуникационный процесс, кивок.

It should be particularly noted that the following scholars studied the specifics of communication means: Polivanov E. D., Iakubinskii L. P., Kapanadze L. A., Krasilnikov E. V. and other linguists.

Polivanov E. D. identified three kinds of information transmitted in a nonverbal conversation: symbolic, expressive, and descriptive. Iakubinskii L.P. also identified three kinds of elements: mimics, gestures and various body movements.

Kapanadze E. V. and Krasilnikov L. A. having studied nonverbal communication means separated them into indicative, fiction, symbolic, as well as expressed the ideas on availability of rhythmic and emotional signs. 
The abovementioned researchers underlined a special methodology and research significance of understanding various movements of the body, awareness or universal nonverbal means in communication, used to exchange opinions and their meaning.

Scholar Botobekova A. having studied the specifics and structures of non-verbal communication in the Kyrgyz linguistics analyzed the available means in accordance with the semantics, as well as divided the main means used in a conversation according to signs into the following groups: fiction, indicative, symbolic and emotional.

The face expression and gestures as well as the language also develop, update, transform based on political and social cultural impacts. As a result, separate mimics and gestures are excluded from the verbal talk and are not used in a conversation. They include: scratch the face, close the face, kiss theskirting, provide respect, kiss the land, kiss the sword, hang the whip on the neck, enterdragging the whip, fall on knees, sit with legs underneath one on another, bow, other similar signs can be listed here [4, p. 21].

According to the established goals based on an example of extracts from the text of the novel by Kasymbekov T. "Broken sword" we will analyze transfer in a fiction text of symbolic mimics gestures, which are not used in spoken speech, with the development of the society, technique, civism, their semantics, as well as the functions of separate non-verbal means used in exchange of opinions at the present time. For instance:

1.Scrach ones' face (perish, feel sad, suffer) - is ritual of a woman, who lost her husband, who as a rule in order to express all the heaviness of her fate scratched her face into blood. The fact that this tradition was used by the Kyrgyz people since old ages is confirmed by historic facts. Acustomtoscratch one's face was used only by those women, who lost the most close and respected people [4, p. 113] For instance:

1. One's again burning Aizada opened her eyes

-what about me - short of breath she pulled her hands from the women, who held her and cried and scratched her face into blood, which poured from her face on both sides of her face [3, $\mathrm{p}$. 28]

This action practically is not used today, but the reader, no matter what book he reads, learning about the traditions typical of the Kyrgyz people learns about this ritual sign, and at present a person, who loses the most closed relative, uses a reminiscence song and a tradition to wear black.

2.Show respect (respect, attitude, esteem, sanctity) - this action means to greet with both hands, welcome by taking hands to chest, bow, take to eyes and kiss a subject which is sacred or hands, skirting of a person, who committed a hajj, by committing such gestures - the mimic of a person expresses respect and attitude. For instance:

1.Abdyrakhman took a roll of paper sealed with the seal of the Khan with both hands and with respect raised the roll up and expressed his respect by taking it to the front and lips.... [3, p. 34]

2.Sherali could not rise his eyes and obviously expresses his respect by a bow to the skirting of a black and coloredvelvet of a coat of his uncle [3, p. 41]. Nuzup narrowed his eyes, bowed and quietly expressed his respect by taking with both hands Ajibay Datka's hand [3, p. 42].

4.Kurmanjan slightly short of breath from an exclamation quietly fell to knees and held with both hands the hand of the master grasped it with respect to the red front and quietly expressed her respect [3, p. 211].

At present time, this action on showing respect practically not used except of one instance. Thus, for instance all know that at a ceremony (inauguration) the elected President of a country by expressing his allegiance to the people, willingness to serve with his heart, at a ceremony of swearing in order to express his respect kisses the edge of the state flag, puts his hand on the Constitution of the Republic or the Holy Koran. 
3. Stand on knees, drop on one's knees (beseech to pardon) - this action expresses to seek pardon from anyone for one's actions. [4, p. 109] For instance:

1.Narmambet Datka clutched. The face became sweat and became blue black, tears fell from the corners of his tight narrowed eyes. His back began to shake and he no longer was able to hold himself and burst into tears.

He stood and bowed his grey head in front of Kudaiar Khan:

-O my Master here I fall to your feet... If Musulmankul did not fall, then I will fall, I beg you I will subordinate... O, Khazratistopthebattle, O khazrati...

KudaiarKhanwatched frowned. Having seen that he is not subject to Narmambet Datka ones again bowed and quietly fell with the front to the land [3, p. 181].

2.Having felt that she may be subject to hard questioning with a bitting hart and shacking body Kanat having held his both hands to his chest bitting his front against the land fell on the knees... [3, p. 207]

In a society we live, the responsible party does not beg pardon on the knees, however, if a person feels guilty, he asks pardon and promises to no longer repeat his mistake, we know that our people are generous and in order to improve relations proceeds from a position existing for a long time: "give your mother to the one, who killed your father." If in front of your came a person with guilt, give up wergild for your father. A sword does not cut a guilty head".

4. When bowing a respectful bow is welcomed (respect, esteem, polite bow) - is an action when the addressee welcomes in a slightly bowed position, by holding his hands to the chest or with both hands, which expresses the feeling of respect, esteem, welcome the interlocutor [4, p.118].

1. The waiting people pushing from all sides gathered in the center then split in the middle by opening the road, bowed and welcomed by a hollow rumple and grasping hands to the chest and followed [3, p. 44].

2. The history to bow begins from the epic "Manas" - our ethnographic source. In the epic, the daughter of Kaiyp Karabork was a hunter. When Manas destroyed everyone and freed the Kyrgyz lands, Karabork with an arrow wounded Bakai. Because Bakai at that time was young, he could escape the arrow and the arrow got into his hip. After the victory of Batyr Manas Akbalta said: "It is not right that a young Khan is single." In addition, at fifteen married him off to Karabork. Karabork, being embarrassed, by her deed escaped Bakai. And in those instances when it was impossible to escaped him, bowed and passed by. She will not have to repeat: "Excuse me!"Since that time a tradition started that the daughter-in-law should escape the oldest brother and when meets him shall bow to the oldestbrother of her husband. Today, our fellow citizens at Issyk$\mathrm{Kul}$ follow this tradition as in the old times. Even a ninety years old woman bows to the elder men of her husband [2, p. 208].

If you take the old culture concerning a polite bow, we know that Japanese and Chinese also have a tradition to bow. Take for instance the Japanese, because in their life this movement has a special meaning, and even during a phone call they bow. Moreover, they do not see their interlocutor or each other. The flexibility and duration of a bow differs depending on a situation, in which you have to bow. This action is exercised depending on the degree of respect, social status or whom you should bow to. Moreover, tobowmeanstowelcome, thank, asktoforgive, andtocongratulate. 
With the Japanese bowing has many other meanings:

1.To nod (band one's head at 5 degrees) is when a person bows by a shorttime movement making one time a nod up and down. This is how friends and people with a similar statuswelcome each other.

2. To bow symbolizes a welcome (Esiaku, at 15 degrees) - this is how people of different status greet each other. They may be good acquaintances but not very close, so that they nod their heads.

3. To bow in order to express respect (keyrey, at 30 degrees) - is an action is exercised with high flexibility, maily in respect to people with a higher status, for instance, the head or teacher.

4. To bow in order to express one's highest respect (sykayray, at 45 degrees) - people bow this way only to the Emperor or when they ask for a pardon. This means a high level of sorry or respect.

5. To bow (bow to the land) - this action is rarely used today and exercised when one asks for a pardon for commitment of highly dangerous crimes.

Although the Japanese do not expect that foreigners will bow but are very happy when you bow in return. If the status of a person is hard to tell, it is enough to bow at 30 degrees [7, p. 2].

Unlike the Japanese, the Chinese do not bow when they say good-bye or welcome. They bow in especially ceremonial events in order to express respect. The lower is the bow the deeper is respect to a person.

During the times of the Chinese dynasty, it was a sign of respect, when guests, who came to the Emperor, lied down on the land nine times touched the land by their heads. This movement is used today in cathedrals in respect of Buddhist statues. This is used as a sign of respect to the dead, or as a sign of respect to the church. The Chinese bow to say good-bye or by a nod express their respect only sometimes [6, p. 1].

Unlike the Chinese the Koreans' deep bows mean welcome or request to ask may be at 30 to 90 degrees.

Moreover, the one, who has a lower status or is younger, bow lower and longer. To simply bow with one's head is impolite. Many Koreans, when they welcome, also follow a Western tradition to shake hands additionally put their hands to the heart or touch the hand above the stretched hand and nod. If a person has a social status higher or older than you are, it is considered as a bad tone to first take backhand. This tradition is found in Korea, everywhere (even at shops, in supermarkets, at car parking). Thismovementin Koreaniscalled "Insa". Starting from a kindergarden the teachers teach children to welcome or aks for pardon. A bow, when children bow to the elders by putting both hands to their chest, is called "chol" and is an expression of the highest respect. This bow concerns also the dead grandfathers and grandmothers. "Chol" is used for the life one time and before the dead three times. Moreover, people bow with both hands up front until the head touched the land [5, p. 2].

We all know that the Kyrgyz since long ago to nowadays use a tradition when a young man or young girl, who have just created their families, bow to the relatives from both sides.

A tradition to bow is typical of women particularly daughters-in-law. A daughter-in-law shall shows respect and bow to the elders in their family, father-in-law, mother-in-law, elder brothers of her husband. To bow with the hands crossed on the chest is a respect in relation to the elders. In return, they get blessings from aksakals. A tradition to bow has their territorial specifics. Even having reached the age of 70-80 years old, people bow to show respect to the elders.

5. Blessings, pray (memory for the dead, reading of Koran in their honor, wishes) -a traditional ritual, which is referred to a tradition and custom and is used in order to memorize, 
success in any action, or wish evil or damnation (moreover, the face is touched with the back side of the palms).

1.-Brother Nuzup, you started a difficult work...-said he thoughtfully.- Nevertheless, you can take the work to the end; the force of time is on your side. The lake is not always calm and it is stormy from a storm. Thepeoplearelikethelake. A storm of Nasurulla lhan-Batyr seems to frighten a little but it shake the society. Do not get modest, take a house and go ahead. At a different time, you will not be able to gather and take people to hunt. If you now can raise the spirit of the people and then take for them, then the mudslide will cover everything where you go. You could feel this it is a good brother, you have a sound mind and feeling. Goodway. Letthespiritofthepredecessorssupportyou. Omen!... They said having opened their bony thing hands and touched the face to pronounce a blessing [3, p. 42].

2. Kasym minbashi raised his hand up high and opened the palm and wished Kudaiar Khan wellbeing:

-Omen!- he touched the face while reading a blessing. The people with noise raised their heads stretched hands to the sky and loudly accompanied the blessing by the words: "Omen!" [3, p. 171]

At present time, blessing is used to not only purely in a religious meaning, but also as a wish of success in case of any action. Because with time the sphere of use of an action to bless widened, it is committed not only when reading the Koran for the dead, but also before travel when meeting guests after treatment.

A writer in his book draws a world, therefore, the reader should learn to "see" what the painter would like to say in the future. Be it the main character, a description of a screen, in one world it is significant to predict, what the writer would like to say, to feel the writer's idea.

In order to differentiate the functions and semantics of symbolic signs, nonverbal means, facial expression and gestures creative fantasy, inspiration and high degree of imagination isused by the writer when creating fiction.

References:

1. Botobekova, A. (2007). Kyrgyz facial expressions-gestures. Bishkek.

2. Kadyrov, Y. (2011). Drops of Kyrgyz culture. Bishkek.

3. Kasymbekov, T. (1998). Broken sword: historical novel. Revised. Bishkek

4. Konkobaev, K., \& Botobekova, A. (2007). Explanatory dictionary of Kyrgyz expressions, gestures, Bishkek.

5. De Mente, B. L. (2011). Korean business etiquette: The cultural values and attitudes that make up the Korean business personality. Tuttle Publishing.

6. Worldskills International https://enterchina.ru/blog/kit

7. Otsubo, M. (1986). A Guide to Japanese Business Practices. California Management Review, 28(3).

\section{Список литературь}

1. Ботобекова А .Кыргызские мимики-жесты. Бишкек, 2007.

2. Кадыров Ы. Капли кыргызской культуры Бишкек, 2011.

3. Касымбеков Т. Сломанный меч. Бишкек, 1998.

4. Конкобаев К., Ботобекова А. Толковый словарь кыргызских мимик-жестов. Бишкек, 2007.

5. De Mente B. L. Korean business etiquette: The cultural values and attitudes that make up the Korean business personality. Tuttle Publishing, 2011. 
6. Worldskills International. https://enterchina.ru/blog/kit

7. Otsubo M. A Guide to Japanese Business Practices //California Management Review. 1986. Vol. 28. №3.

Работа поступила

Принята к публикацฺии

в редакичию 08.02.2020 2. 11.02.2020 2.

Ссылка для циитирования:

Eltuzerova G. Functions of Symbolic Signs of Gestures and Facial Expressions in Fiction (Based on the Material Broken Sword Novel by T. Kasymbekov) // Бюллетень науки и практики. 2020. T. 6. №4. C. 536-541. https://doi.org/10.33619/2414-2948/53/65

Cite as (APA):

Eltuzerova, G. (2020). Functions of Symbolic Signs of Gestures and Facial Expressions in Fiction (Based on the Material Broken Sword Novel by T. Kasymbekov). Bulletin of Science and Practice, 6(4), 536-541. https://doi.org/10.33619/2414-2948/53/65 